\title{
THE LINK BETWEEN FROM DAY TO DAY CHANGE OF WEATHER TYPES AND SYNOPTIC SITUATIONS IN KRAKÓW DURING THE PERIOD 1961-2010
}

\author{
Katarzyna Piotrowicz, Joanna Szlagor \\ Institute of Geography and Spatial Management, Jagiellonian University, Kraków, Poland
}

Manuscript received: January 17, 2013

Revised version: July 5, 2013

Piotrowicz K., Szlagor J., 2013. The link between from day to day change of weather types and synoptic situations in Kraków during the period 1961-2010. Quaestiones Geographicae 32(2), Bogucki Wydawnictwo Naukowe, Poznań, pp. 69-84. 2 tables, 9 figs. DOI 10.2478/quageo-2013-0023, ISSN 0137-477X.

\begin{abstract}
AвSTRACT. This paper analyses day-to-day changes of weather types and links these with synoptic situations, i.e. circulation types, air masses and weather fronts. The weather types were classified according to Woś (1999), while a calendar proposed by Niedźwiedź (2013) was used for synoptic situations. Weather records from Kraków were used covering the period 1961-2010. The frequency of all combinations of day-to-day weather type changes was calculated, identified using specific values of air temperature, cloudiness and precipitation. The analysis of the succession and frequency of the day-to-day changes was linked with the synoptic situations accompanying the change. It was found that the thermal weather types were relatively very stable and remained unchanged on the following day in $61.3 \%$ of cases, and that the synoptic situation also remained similar. Weather subtypes, identified with just cloudiness and precipitation, but not temperature, displayed much more day-to-day change in terms of frequency and scale. Synoptically it was the air mass change and/or the occurrence of atmospheric fronts, which tended to cause day-to-day weather type changes, while the impact of circulation was not always clear. Particular attention was devoted to sudden weather type changes caused primarily by dramatic air temperature fluctuations.
\end{abstract}

KEY WORDS: weather types, circulation types, synoptic situations, day-to-day change, Kraków

Address of the corresponding author: Katarzyna Piotrowicz, Institute of Geography and Spatial Management, Jagiellonian University, Gronostajowa 7, 30-387 Kraków, Poland; e-mail: k.piotrowicz@uj.edu.pl

\section{Introduction}

Complex climatology defines climate as a "long-term pattern of local weather manifested as a certain order of occurrence of all weather types observed in a given area" (Chubukov 1962). Contemporary climatological writing defines the climate as "a regular succession of atmospheric change in a given location or geographical region" (Woś 1999).
Elements of weather exert a combined fundamental influence on the natural environment and on the life and activity of humans (Ahas et al. 2005). Long spells of high temperature, or sudden changes to it, may have a range of different effects on living organisms. A separate analysis of individual elements of weather is insufficient for a full account of the local climate. This task essentially requires an analysis of the frequency of the various weather situations, known as weather types, 
and their seasonal variability. Such an analysis can benefit from the determination of the frequency of day-to-day change of weather types. Indeed, short-term weather patterns, such as the succession of weather types, are important for practical purposes. Linking day-to-day weather changes with synoptic situations (i.e. atmospheric circulation, air masses and fronts) offers valuable insights in many aspects of science, whether in terms of methodology or pure and applied research.

The term "type of weather" is used by complex climatologists, synoptic meteorologists and synoptic climatologists, which sometimes leads to misunderstandings about its meaning. In complex climatology the weather type is understood as the daily pattern of the various meteorological elements (Piotrowicz 2010), while in synoptic climatology it is defined as the effect of a classification of atmospheric circulation types (Stefanicki et al. 1998, Sheridan 2002, 2003, Brown 2004).

Fedorov (1925) pioneered the analysis of climate and the method of using a daily weather catalogue coded with letters. His method was rather complicated, as it coded a wide range of elements, including: the average daily air temperature in certain intervals, the maximum and minimum temperature, the difference between current and previous-day temperature, relative humidity, precipitation, wind speed and direction and ground condition (Zinkiewicz 1953). Chubukov (1949) modified Fedorov's classification and used it for bioclimatic research.

The earliest attempts to classify weather types were published in the USA in the first half of the 1920s. The authors used either momentary weather situations or their 24-hour records from stations located in South America (Howe 1925), the USA (Nichols 1925), Mexico and Central America (Howe 1925, Switzer 1925).

Weather types are treated as components of climate, while air temperature, cloudiness and precipitation are regarded as elements of the weather (Woś 1999). As such they provide a general description of the weather, while their frequency of occurrence constitutes a source of information about the climate in a given location.

Kraków is among a small group of European cities with long and unbroken meteorological records. The city has a moderate transitional climate characterised by frequent weather changes due to the meeting of dry air masses from the inner part of the continent and humid air from the Atlantic.

Few studies are available linking a comprehensive approach to weather with circulation types (Bogucki, Woś 1994, Kaszewski 1984, 1992, Nagórska 1998, Niedźwiedź 1981, 1983, 1988, Więcław 2004). Indeed, this approach tends to be inherently complex, including from a methodological point of view.

Petrovič (1968) was among the researchers who investigated the weather in connection with circulation types. He used a modified version of the Fedorov-Chubukov classification and circulation types according to CHMU. Maheras (1984) also relied on the Russian climatological classification in his comparative study of weather patterns in Thessaloniki. Michailidou et al. (2009a, b) followed this vein of research. They identified weather types using concentration analysis and two data groups, i.e. on meteorology and circulation. In Poland similar research was conducted, among others, by Niedźwiedź (1981, 1983), Kaszewski (1984, 1992) and Bogucki and Woś (1994). The latter two, in a study of relationships between weather types and circulation types near Poznan, allocated one weather and one circulation type to each day of their study period. They then calculated the average annual frequency of weather types and circulation types and the frequency of occurrence of each weather type during the circulation types.

This study aimed to evaluate the influence of the synoptic situation on day-to-day weather changes in Kraków during the period 1961-2010. The first step was to identify the weather types on each day of the study using the classification by Woś (1999). Then, the frequency of day-to-day weather type changes was calculated and linked to the synoptic situation (circulation type, air mass and atmospheric front) on that day. A simple method proposed for the analysis of the dayto-day weather change linked to synoptic situations brought interesting insights into short-term weather variability in the study area. 


\section{Source material}

It follows from the premises of complex climatology that the climate should be studied using information on the weather and its longterm patterns. The inherently great variety of weather situations calls for a generalisation to be made, which takes the form of the classification of weather types. Complex climatology uses a range of criteria and combinations of the elements of weather to arrive at weather type classifications. Weather types are normally classified on a daily scale using sets of weather elements. As a result, each day is characterised by its date and the appropriate numerical values.

This study used daily values of selected weather elements recorded at the Climatology Department's Research Station $\left(50^{\circ} 04^{\prime} \mathrm{N}\right.$, $19^{\circ} 58^{\prime} \mathrm{E}, 220 \mathrm{~m}$ a.s.1.) covering the period 19612010. Weather types were determined using the classification proposed by Woś, which involved air temperatures (daily average, maximum and minimum), average cloudiness (as a percentage) and the total daily precipitation (day with and day without precipitation) (Table 1). The classi- fication by Woś, published in 1999, was slightly modified by adding a warm weather type (coded 22 ) to the thermal weather classification. The author found it useful to expand the existing range of three thermal weather types characteristic of the warm half of the year, which, with the 10-degree range of the average daily temperature per type, was rather limiting for the understanding of summertime weather variability. As a result, 12 ranges of daily average air temperature were adopted, three ranges for overall cloudiness and two ranges for precipitation. Overall, 66 types of weather were identified, each coded with three digits (four in the hot weather type 33 and warm type 22), the first of which (the first two in types 33 and 22) denoted temperature characteristics, the second denoted cloudiness and the third gave information about precipitation.

Weather types can also be coded with less than all three elements of weather. For example, a type coded as 10- denotes cool weather with low cloudiness and is determined with the average, maximum and minimum temperatures and with cloudiness. A type coded as 22- means warm weather, but makes no reference to the

Table 1. Weather types classification by Woś (1999)

\begin{tabular}{|c|c|c|}
\hline Code & Criterion & Names of weather \\
\hline \multicolumn{3}{|c|}{ Air temperature } \\
\hline 33-- & $\mathrm{t}_{\text {mean }}>25.0^{\circ} \mathrm{C} ; \mathrm{t}_{\text {min }}, \mathrm{t}_{\text {max }}>0.0^{\circ} \mathrm{C}$ & hot \\
\hline 3-- & $\mathrm{t}_{\text {mean }} 15.1-25.0^{\circ} \mathrm{C} ; \mathrm{t}_{\text {min }}, \mathrm{t}_{\max }>0.0^{\circ} \mathrm{C}$ & very warm \\
\hline $22--$ & $\mathrm{t}_{\text {mean }} 10.1-15.0^{\circ} \mathrm{C} ; \mathrm{t}_{\text {min }}, \mathrm{t}_{\text {max }}>0.0^{\circ} \mathrm{C}$ & warm \\
\hline $2--$ & $\mathrm{t}_{\text {mean }} 5.1-10.0^{\circ} \mathrm{C} ; \mathrm{t}_{\text {min }} \mathrm{t}_{\text {max }}>0.0^{\circ} \mathrm{C}$ & moderately warm \\
\hline 1-- & $\mathrm{t}_{\text {mean }} 0.1-5.0^{\circ} \mathrm{C} ; \mathrm{t}_{\text {min }} \mathrm{t}_{\text {max }}>0.0^{\circ} \mathrm{C}$ & cool \\
\hline 4-- & $\mathrm{t}_{\text {mean }}>5.0^{\circ} \mathrm{C} ; \mathrm{t}_{\min } \leq 0.0^{\circ} \mathrm{C} ; \mathrm{t}_{\max }>0.0^{\circ} \mathrm{C}$ & ground-frost, moderately cool \\
\hline 5-- & $\mathrm{t}_{\text {mean }} 0.1-5.0^{\circ} \mathrm{C} ; \mathrm{t}_{\min } \leq 0.0^{\circ} \mathrm{C} ; \mathrm{t}_{\max }>0.0^{\circ} \mathrm{C}$ & ground-frost, very cool \\
\hline 6-- & $\mathrm{t}_{\text {mean }}-5.0-0.0^{\circ} \mathrm{C} ; \mathrm{t}_{\min } \leq 0.0^{\circ} \mathrm{C} ; \mathrm{t}_{\text {max }}>0.0^{\circ} \mathrm{C}$ & ground-frost, moderately cold \\
\hline 7-- & $\mathrm{t}_{\text {mean }}<-5.0^{\circ} \mathrm{C} ; \mathrm{t}_{\min } \leq 0.0^{\circ} \mathrm{C} ; \mathrm{t}_{\text {max }}>0.0^{\circ} \mathrm{C}$ & ground-frost, very cold \\
\hline 8-- & $\mathrm{t}_{\text {mean }}-5.0-0.0^{\circ} \mathrm{C} ; \mathrm{t}_{\text {min' }} \mathrm{t}_{\text {max }} \leq 0.0^{\circ} \mathrm{C}$ & moderately frosty \\
\hline 9-- & $\mathrm{t}_{\text {mean }}-15.0 \div-5.1^{\circ} \mathrm{C} ; \mathrm{t}_{\text {min }}{ }^{\prime} \mathrm{t}_{\max } \leq 0.0^{\circ} \mathrm{C}$ & fairly frosty \\
\hline $0--$ & $\mathrm{t}_{\text {mean }}<-15.0^{\circ} \mathrm{C} ; \mathrm{t}_{\min } \mathrm{t}_{\max } \leq 0.0^{\circ} \mathrm{C}$ & very frosty \\
\hline \multicolumn{3}{|c|}{ Cloudiness } \\
\hline$-0-$ & $\mathrm{N} \leq 20 \%$ & sunny or with little cloud amount \\
\hline$-1-$ & N 21-79\% & cloudy \\
\hline$-2-$ & $\mathrm{N} \geq 80 \%$ & very cloudy \\
\hline \multicolumn{3}{|c|}{ Precipitation } \\
\hline--0 & $\mathrm{P}<0.1 \mathrm{~mm}$ & day without precipitation \\
\hline--1 & $\mathrm{P} \geq 0.1 \mathrm{~mm}$ & day with precipitation \\
\hline
\end{tabular}


Table 2. Synoptic situations, air masses and fronts for southern Poland by T. Niedźwiedź (2013)

\begin{tabular}{|c|c|}
\hline Code & Circulation types \\
\hline $\mathrm{Na}$ & anticyclonic situation with an advection of air masses from the north \\
\hline NEa & anticyclonic situation with an advection of air masses from the northeast \\
\hline Еa & anticyclonic situation with an advection of air masses from the east \\
\hline SEa & anticyclonic situation with an advection of air masses from the southeast \\
\hline Sa & anticyclonic situation with an advection of air masses from the south \\
\hline SWa & anticyclonic situation with an advection of air masses from the southwest \\
\hline Wa & anticyclonic situation with an advection of air masses from the west \\
\hline NWa & anticyclonic situation with an advection of air masses from the northwest \\
\hline $\mathrm{Ca}$ & central anticyclonic situation, lack of advection, centre of high pressure \\
\hline Ка & $\begin{array}{l}\text { anticyclonic wedge, sometimes a few non-definite centre or unconstrained area of higher pressure, } \\
\text { axis of high pressure ridge }\end{array}$ \\
\hline Nc & cyclonic situation with an advection of air masses from the north \\
\hline NEc & cyclonic situation with an advection of air masses from the northeast \\
\hline Ec & cyclonic situation with an advection of air masses from the east \\
\hline SEc & cyclonic situation with an advection of air masses from the southeast \\
\hline SEc & cyclonic situation with an advection of air masses from the south \\
\hline SWc & cyclonic situation with an advection of air masses from the southwest \\
\hline Wc & cyclonic situation with an advection of air masses from the west \\
\hline NWc & cyclonic situation with an advection of air masses from the northwest \\
\hline Cc & central cyclonic situation, centre of low pressure \\
\hline Bc & $\begin{array}{l}\text { cyclonic trough or unconstrained area of low pressure, or axis of the low pressure trough, with } \\
\text { various advection directions and system of fronts separating different air masses }\end{array}$ \\
\hline $\mathrm{x}$ & col and situations which cannot be classified \\
\hline \multicolumn{2}{|r|}{ Air masses } \\
\hline PA & Arctic \\
\hline PPm & Polar maritime fresh \\
\hline PPms & Polar maritime old (transformed) \\
\hline PPmc & Polar maritime warm \\
\hline PPk & Polar continental \\
\hline PZ & Tropical \\
\hline $\mathrm{rmp}$ & Various air masses \\
\hline \multicolumn{2}{|r|}{ Fronts } \\
\hline- & day without front \\
\hline c & warm front \\
\hline $\mathrm{z}$ & cold front \\
\hline $\mathrm{o}$ & occluded front (occlusion) \\
\hline $\mathrm{s}$ & stationary \\
\hline $\mathrm{rf}$ & several various fronts \\
\hline
\end{tabular}

cloudiness or precipitation. Such weather types are referred to as "thermal types". A weather type coded -10 means cloudy weather without precipitation, but without reference to the temperature, and is referred to as a "subtype".

Day-to-day changes of the thermal types, subtypes and full weather types were linked with types of circulation, air masses and atmospheric fronts in accordance with a classification devised by Niedźwiedź (2013). This classification has been widely used in climatological research, and detailed accounts of it can be found for example in paper by Twardosz et al. (2011). Niedźwiedź
(2013) identified 21 types of synoptic situations (Table 2), including one (x), which either cannot be classified or is a col. One half of the 20 definite synoptic situations are cyclonic and the other half anticyclonic. For the sake of clarity the author coded advection directions with letters and added the index $a$ for high pressure and $c$ for low-pressure systems. Out of the 20 situations 16 have a specific advection direction, while the remaining four either have no advection at all or the airflows from varying directions.

The same classification was used to determine the type of air masses over southern Poland and 


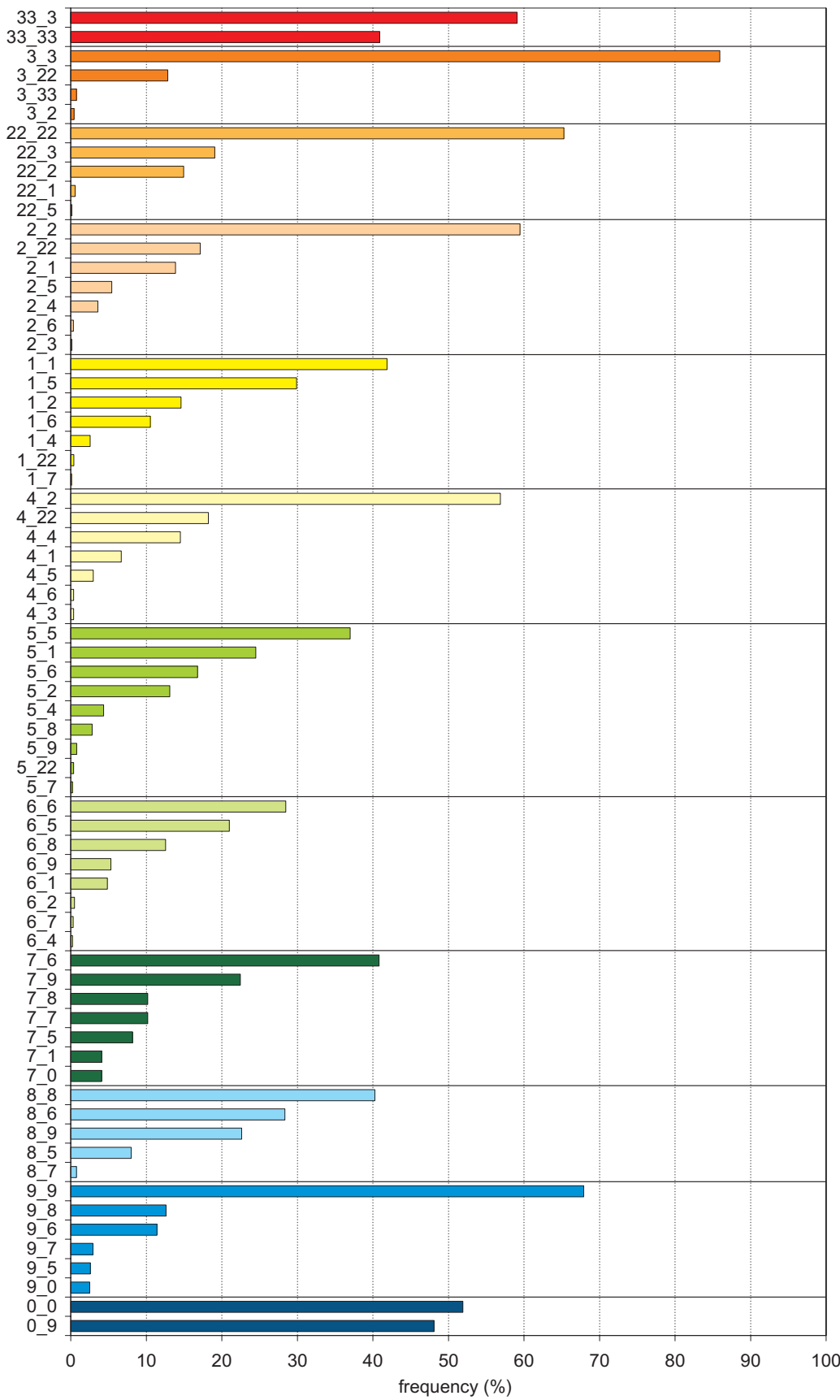

Fig. 1. Frequency of occurrence (\%) of day-to-day change of thermal types of weather in Kraków during the period 1961-2010

the passage of atmospheric fronts. The relevant description is found in Table 2.

\section{Day-to-day change of thermal weather types}

It is useful to begin the study of day-to-day weather change by investigating thermal weather types. Figure 1 illustrates the frequency of oc- currence of all possible combinations of day-today change of thermal types of weather during the study period. Out of the total 69 combinations the most frequent were 3_3 (23.8\%), 22_22 $(12.5 \%)$ and 2_2 (9.5\%). This is explained by the fact that these were the most frequent thermal weather types occurring in Kraków (Fig. 2).

Other types of information that can be derived from this analysis include the frequency of dayto-day temperature drop or increase, i.e. when 
thermal types changed, and the frequency of day-to-day weather stability, i.e. when the types remained the same. The study found that during the study period a hot day (33) was followed by a warm day (3) much more frequently than the other way around (59.1\%) (Fig. 1). This meant a drop in temperature by one range in the thermal classification (33_3), and the direction of that change may be denoted as " -1 ". This occurred most frequently in association with a change of air mass (from tropical to various air masses or to polar maritime air) and/or with a passage of a cold front. No clear link could be found between this change and the circulation types (Fig. $3)$. Only two combinations of change occurred involving the (33) type and the other combination involved the same thermal type (33_33; 40.9\%) (Fig. 1). These were relatively mild weather changes, as it would take an increase or drop in the temperature by several thermal ranges, e.g. from warm to ground-frost very cool weather (22_5; change -4) for a change to be regarded as dramatic.

The most frequent weather type (3) was typically followed by the same type of weather $(85.9 \%$; 3 _3) or by a colder type of weather when the following day belonged to the thermal type (22) (12.9\%; change -1) (Fig. 1). This combination (3_22) typically coincided with a day without a front (z_-; 23.1\%) (Fig. 3). Otherwise, it was difficult to find any synoptic pattern, even if this combination most frequently occurred during cyclonic situations with polar maritime air. Day-today change through two thermal types, i.e. from 3 into 2, was far less frequent $(0.4 \%$; change -2$)$.

The warm weather type (22) was also most frequently followed by the same type of weather (Fig. 1). This combination was followed in terms

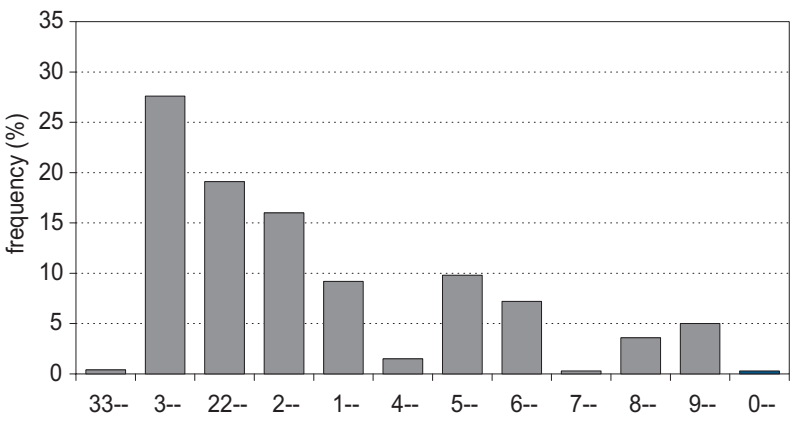

Fig. 2. Frequency of occurrence (\%) of thermal types of weather in Kraków during the period 1961-2010 of frequency by a change to very warm weather $(19.1 \%$; 22_3; change +1$)$. At the other end of the spectrum the change to ground-frost very cool weather (5) produced the greatest day-to-day change (-4), but occurred very rarely (22_5; 0.1\%) (Fig. 1). This change was most frequent $(40.0 \%)$ in connection with the passage of a cold front $\left(-\_z\right)$ and a change of air masses (from various air masses to Arctic air; 40.0\%) (Fig. 3). Circulation types had no significant influence on this type of change.

Days with moderately warm weather (2) were mostly followed by the same weather $(59.5 \%$; 2_2) (Fig. 1). This type, however, was quite often found to change into ground-frost very cool weather $(5.4 \%$; 2_5; change -3) or ground-frost moderately cold weather $\left(0.3 \%\right.$; $2 \_6$; change -4$)$. The latter change occurred in connection with the inflow of Arctic air (rmp_PA; 20\%) (Fig. 3). Neither circulation types nor atmospheric fronts had any apparent influence on that change. There were very few cases $(0.1 \%)$ of the moderately warm weather (2) being followed by a day with a temperature more than $10^{\circ} \mathrm{C}$ higher, i.e. a very warm day (3). When that happened, it was caused by a change from various air masses into tropical air mass (rmp_PZ; 50.0\%; Fig. 3) and typically without atmospheric fronts (-_-; 50.0\%).

More than $80 \%$ of cool days (1) were followed by either the same thermal weather type $(41.9 \%$; $\left.1 \_1\right)$, or by ground-frost very cool weather $(29.9 \%$; 1_5) or by moderately warm weather $\left(14.6 \% ; 1 \_2\right)$ (Fig. 1). Ground-frost moderately cold days followed in $10.5 \%$ of cases (1_6; change -3 ). In this combination there was no apparent impact of circulation. This combination occurred most frequently during cyclonic situations (12.5\%) with polar maritime old or Arctic air masses (PPms; PA; combined 28.4\%) (Fig. 3). The greatest change from this thermal type involved an dayto-day drop in the average temperature by more than $10^{\circ} \mathrm{C}(0.1 \%$; 1 - ; change -4$)$.

A day with moderately cool frosty weather (4) was typically followed by moderately warm weather (2; 56.9\%) (Fig. 1). That day normally also involved a temperature increase (4_22; 4_1; $24.9 \%$ combined). The change from ground-frost moderately cool to warm weather (4_22; change +3 ) was accompanied by similar circulation types and the same air masses (Fig. 3), but since atmos- 
The change of hot day (33--) into very warm day (3--) (33_3; change -1)
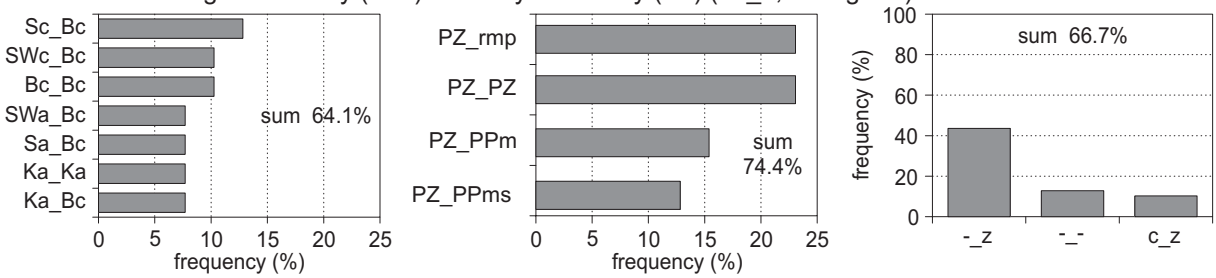

The change of very warm day (3--) into warm day (22--) (3_22; change -1)
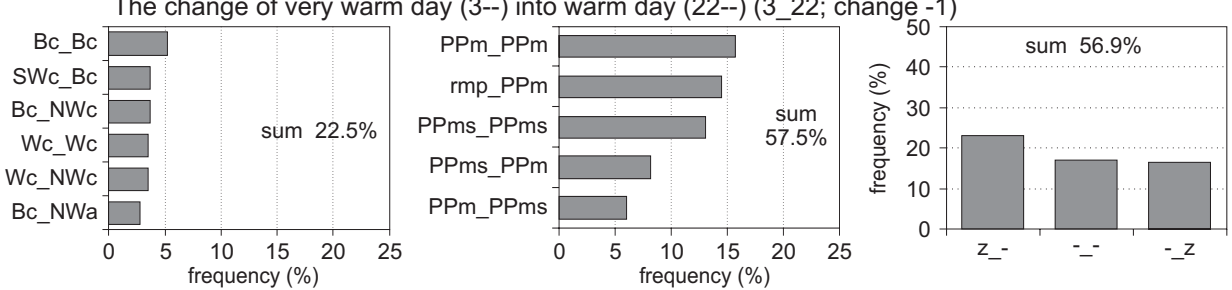

The change of warm day (22--) into ground-frost, very cool day (5--) (22_5; change -4)
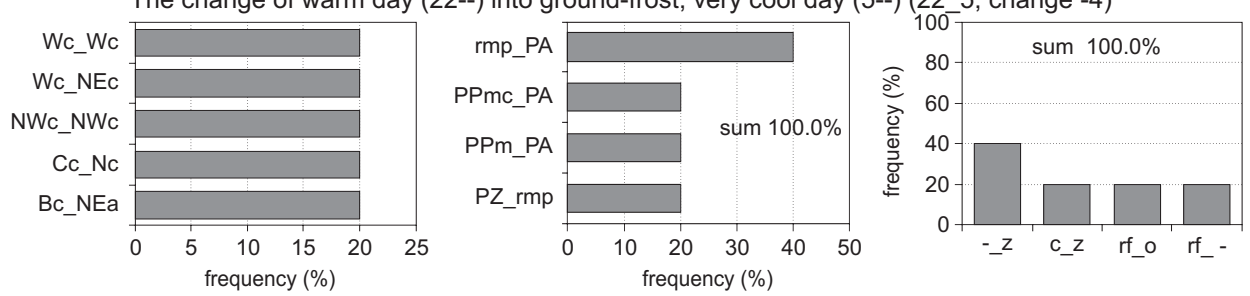

The change of moderately warm day (2--) into ground-frost, moderately cold (6--) (2_6; change -4)
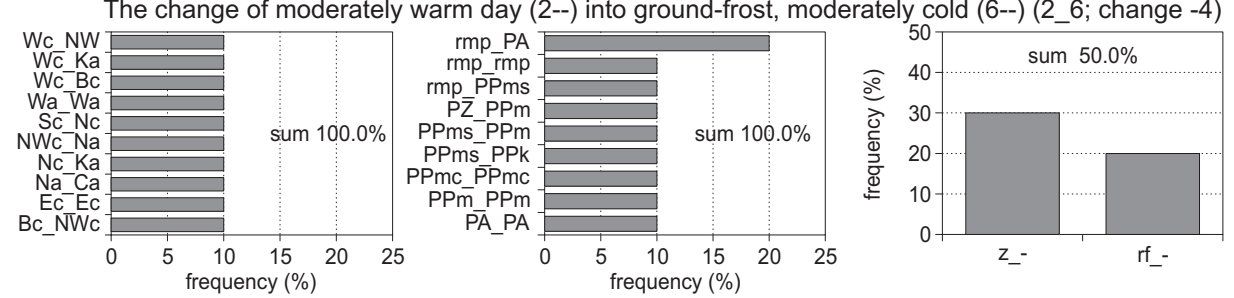

The change of moderately warm day (2--) into very warm day (3--) (2_3; change +2)
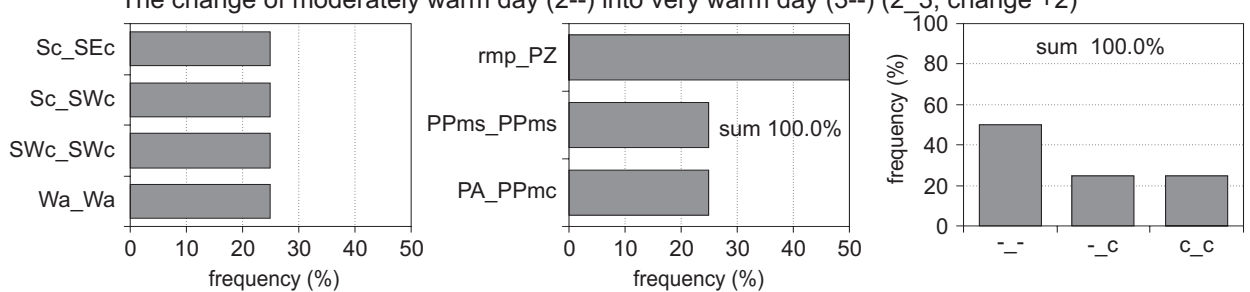

The change of cool day (1--) into ground-frost, moderately cold day (6--) (1_6; change -3)
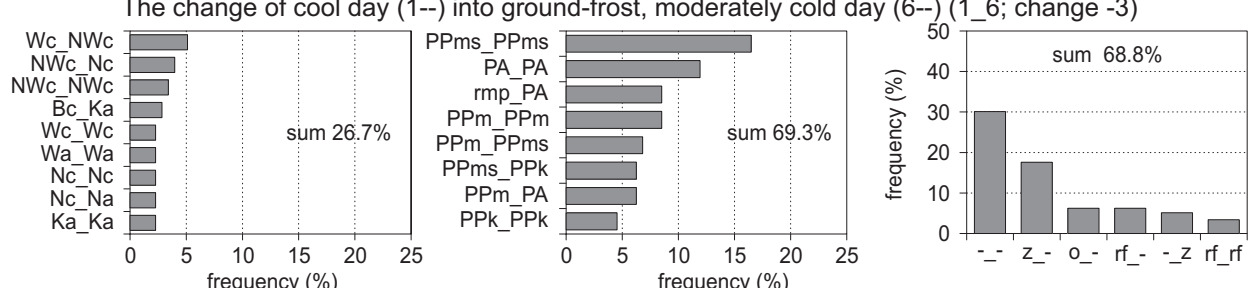

The change of ground-frost, moderately cool day (4--) into warm day $(22--)\left(4 \_22\right.$; change +3)
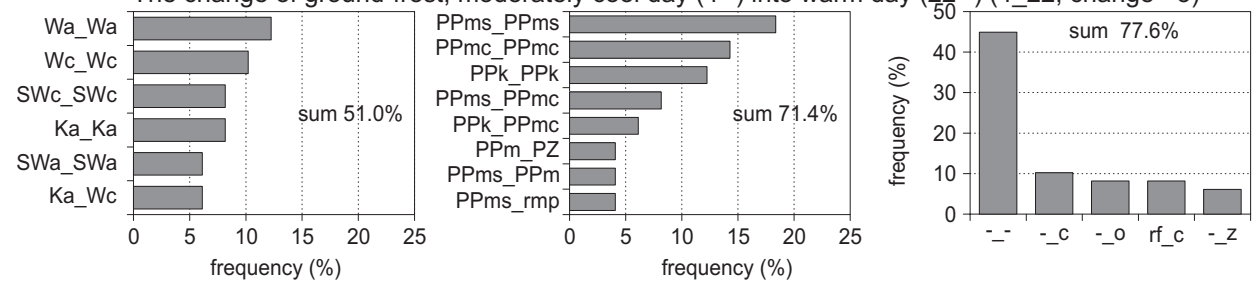

Fig. 3. Frequency of occurrence (\%) of day-to-day change of circulation types, air masses and fronts accompanying changes of selected thermal weather types in Kraków during the period 1961-2010

See Table 2 for abbreviations 
The change of ground-frost, very cool day (5--) into fairly frosty day (9--) (5_9; change -4)
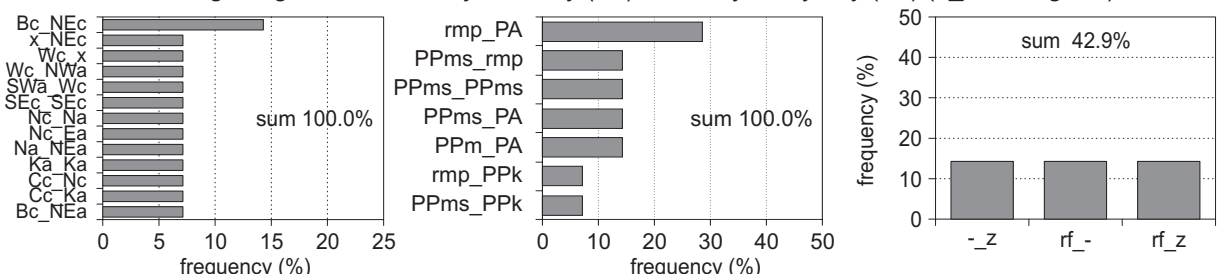

The change of ground-frost, very cool day (5--) into warm day (22--) (5_22; change +4)
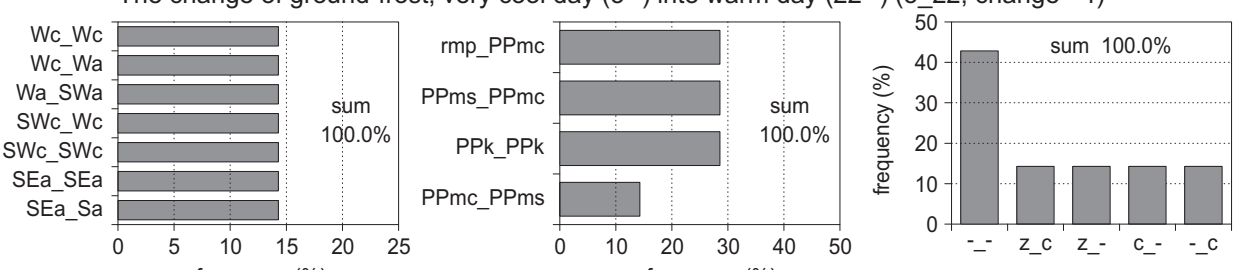

The change of ground-frost, moderately cold day (6--) into ground-frost, very cool (5--) (6_5; change +1)
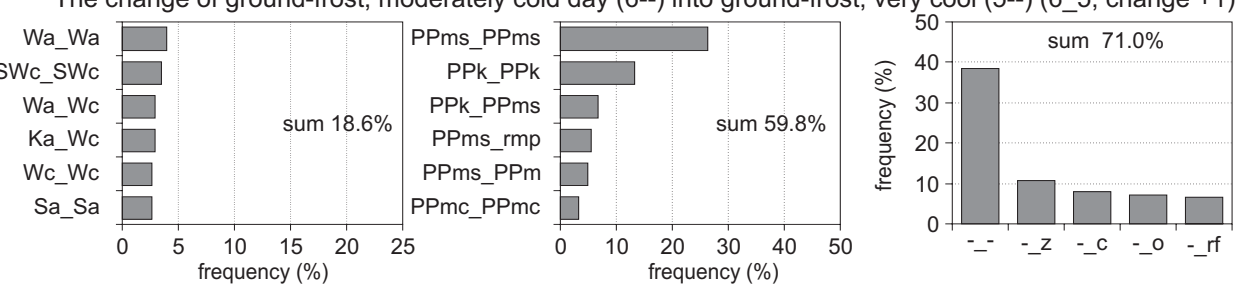

The change of ground-frost, very cold day (7--) into ground-frost, moderately cold (6--) (7_6; change +1)

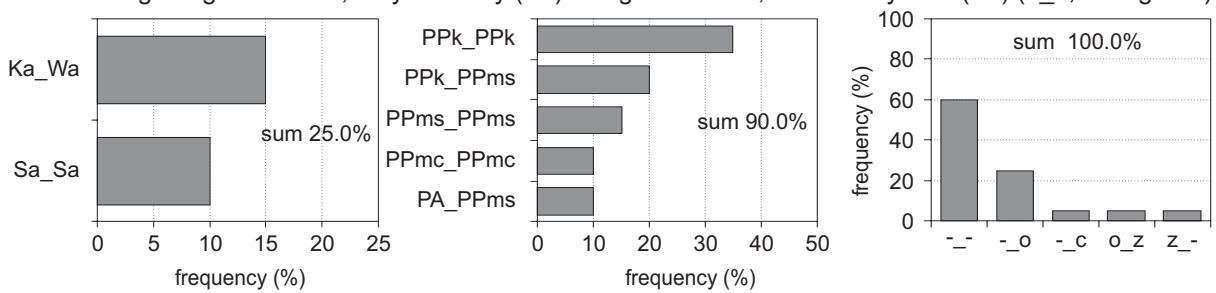

The change of moderately frosty day (8--) into ground-frost, very cool day (5--) $\left(8 \_5\right.$; change +3$)$
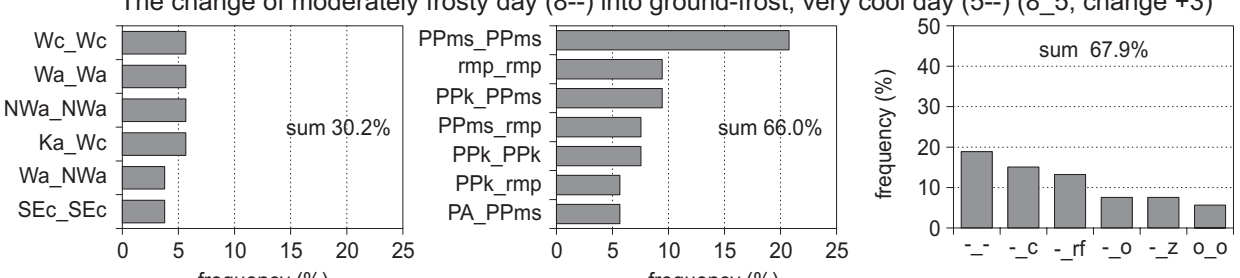

The change of fairly frosty day (9--) into ground-frost, moderately cold day (6--) $(96$; change +3$)$
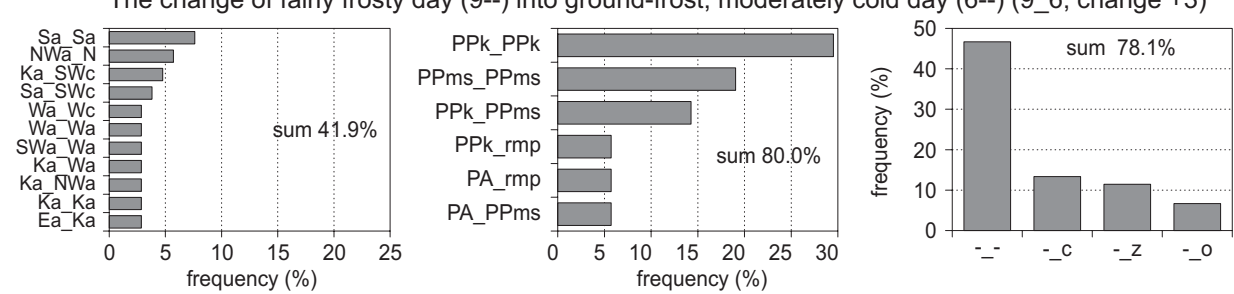

The change of very frosty day (0--) into fairly frosty day (9--) $\left(0 \_9\right.$; change +1$)$
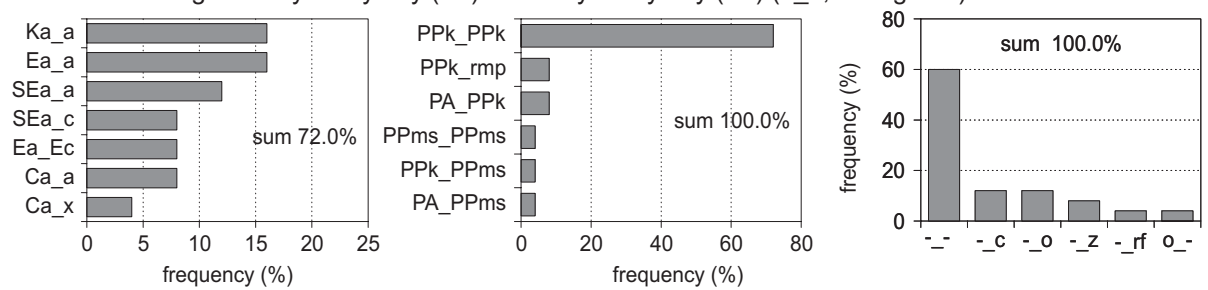

Fig. 4. Frequency of occurrence (\%) of day-to-day change of circulation types, air masses and fronts accompanying changes of selected thermal weather types in Kraków during the period 1961-2010

See Table 2 for abbreviations 
pheric fronts played no significant role the rise of temperature observed would probably be explained primarily by insolation. Extreme cases of a change from moderately cool frosty (4) to very warm weather $\left(0.4 \% ; 4 \_3\right)$ and to ground-frost moderately cold weather $\left(0.4 \% ; 4 \_6\right)$ occurred once in the fifty-year study period. In the former case the temperature surge was caused by the advection of warm air, and in the latter case by the passage of a weather front.

The greatest scale of day-to-day change in temperature occurred after days with groundfrost very cool weather (5) with nine possible combinations of thermal weather types (Fig. 1 ). One of these was a dramatic change from ground-frost very cool to fairly frosty weather (5_9; $0.8 \%)$, which most frequently occurred as varied air masses were replaced by Arctic air (rmp_PA; 28.6\%). A somewhat lesser influence could be attributed to a change from cyclonic trough to a cyclonic situation with northeastern advection (Bc_NEc; 14.3\%) (Fig. 4). Even less frequent was a change from ground-frost very cool to warm weather (5_22; $0.4 \%, 7$ instances, change $+4)$. This typically occurred on days without fronts $(42.9 \%)$ in various kinds of polar maritime air (PPmc, PPms; combined $71.4 \%$ ) or in polar continental air (PPk; 28.6\%) (Fig. 4).

Most days (62\%) with ground-frost moderately cold weather (6) were followed by either ground-frost very cool (5) or moderately frosty days (8) (Fig. 1). There does not seem to be any significant pattern in the 6_5 sequence of thermal weather types. The change was mostly accompanied by anticyclonic circulation and western advection (Wa; $4.0 \%$ ) of polar maritime old air (PPms; 26.3\%) and no frontal activity (38.6\%) (Fig. 4). Days with ground-frost moderately cold weather (6) were also often followed by wide temperature fluctuations, and the following day could belong to any of eight thermal types ranging from moderately warm (2) to fairly frosty (9) (Fig. 1).

The least frequent type of weather overall (7) was typically followed by a day with a different type of weather. That would normally be groundfrost moderately cold weather (6; 7_6; 40.8\%) (Fig. 1). This change was typically accompanied by polar continental air masses (PPk; 35.0\%) and there was a lesser influence of a change in the synoptic situation from anticyclonic wedge to an anticyclonic situation with a western advection (Ka_Wa; 15.0\%) (Fig. 4). The next most frequent successor after (6) was fairly frosty weather (7_9; $22.4 \%$, change -2$)$. The greatest change from (7) was into the cool weather type (7_1; change +4), but only two occurrences of this combination were recorded during the study period $(4.1 \%)$.

A day with moderately frosty weather (8) was typically followed by either the same $(40.3 \%)$ or by warmer weather (37.1\%) (Fig. 1). The next two most likely thermal types of weather included ground-frost moderately cold $\left(6 ; 8 \_6 ; 28.4 \%\right)$ and fairly frosty $\left(9 ; 8 \_9 ; 22.6 \%\right)$. There was also a radical change into ground-frost very cool weather (8_5; 8.0\%, change +3) (Fig. 1). Looking at Figure 3 , it is difficult to find a clear circulation-related source of these day-to-day changes.

The day following fairly frosty weather (9) was most likely to be of the same type (67.9\%) (Fig. 1). Where a change to a higher temperature occurred, it was into types ranging from 8 to 5 . Type (6) had $11.4 \%$ chance of occurring and was often accompanied by polar continental air (PPk; 29.5\%) (Fig. 4). Only $2.5 \%$ of days following type (9) were colder enough to be classified as very frosty (0).

Only two sequence combinations occurred after a very frosty day (0): either the weather continued unchanged $\left(0 \_0 ; 51.9 \%\right)$ or it warmed up to fairly frosty $\left(0 \_9 ; 48.1 \%\right)$ (Fig. 1). The latter change $\left(0 \_9\right.$; change +1$)$ was the most likely $(52.0 \%)$ in a specific range of synoptic situations involving anticyclonic circulation, a set range of air masses (especially polar continental at $72.0 \%$ ) and without fronts (60.0\%) (Fig. 4).

\section{Day-to-day change of weather subtypes}

A similar analysis to the one concerned with the thermal types of weather was carried out with weather subtypes defined by the two other elements of weather, i.e. cloudiness and precipitation. Thirty-six combinations of day-to-day change were identified (Fig. 5), and the most frequent change was from very cloudy days with precipitation $(21 ; 30.8 \%$ of all combinations) and cloudy without precipitation $(10 ; 28.9 \%$ of all combinations) (Fig. 6). 


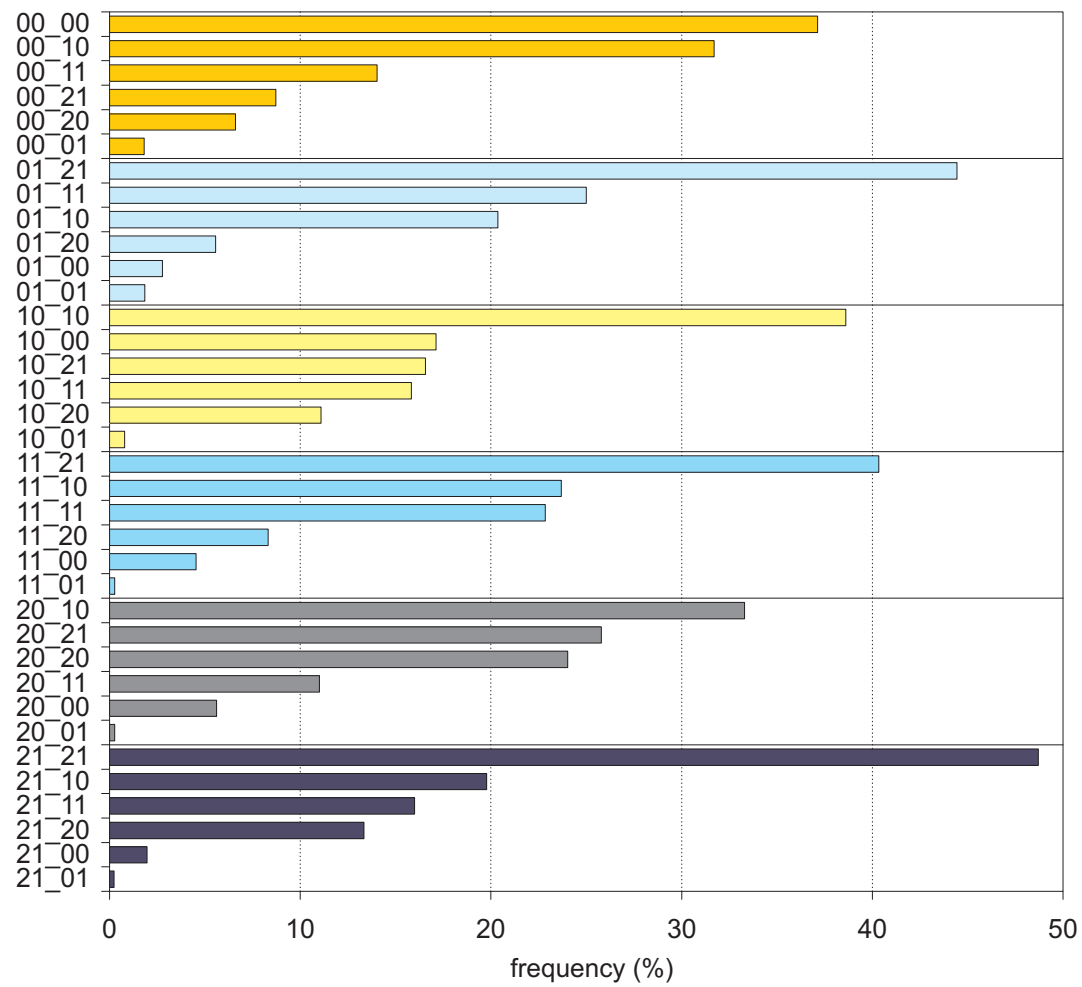

Fig. 5. Frequency of occurrence (\%) of day-to-day change of subtypes of weather in Kraków during the period 1961-2010

A day denoted 00 tended to be followed by a similar day (00_00; 37.1\%) (Fig. 5). Only slightly less frequent was a sequence with a cloudy day without precipitation (00_10,31.7\%). This change was typically (41.5\%) accompanied by polar continental air (PPk) and an anticyclone (Ka; 10.4\%) (Fig. 7). The relatively rare $(8.7 \%)$ sequence of sunny day without precipitation followed by a very cloudy day with precipitation (00_21) was mostly accompanied by a cold front (-_z; 36.2\%) and, much less frequently, by a change from the anticyclonic wedge into a cyclonic trough $\left(\mathrm{Ka}_{-}\right.$ Bc; 6.8\%) (Fig. 7). The least frequent (1.8\%) combination was a sequence of a sunny day without precipitation (00) then a similar day with precipitation (00_01) (Fig. 5).

The least frequently occurring subtype (01; Fig. 6) was most typically (69.4\%) followed also by a day with precipitation (either 21 or 11) and only $28.7 \%$ of the following days were dry $\left(01 \_-\right.$ $0)$. The largest single successor was a very cloudy day with precipitation (01_21, 44.4\%) (Fig. 5). The change of weather from sunny with precipitation into very cloudy with precipitation (01_21) was most frequently $(33.3 \%)$ linked with the passage of a cold front (-_z) (Fig. 7). A lesser influence can be attributed to a change from high to low-pres- sure systems and to polar maritime old air that prevailed on such occasions. Interestingly, there were only two instances when subtype 01 remained the same on the following day $(1.9 \%)$ (Fig. 5).

The typical sequence after both a cloudy day without precipitation $(10 ; 38.6 \%)$ and a very cloudy day with precipitation $(21 ; 48.7 \%)$ was the same weather (Fig. 5). The least frequent change with both subtypes $(10 ; 21)$ was into a sunny day with precipitation (01). Subtype 10 changed into 21 in $16.6 \%$ of cases and occurred most frequently on a day without a front $\left(-\_-; 26.6 \%\right)$ and with polar maritime old air (PPms; 22.6\%) (Fig. 7). A lesser impact would be exerted by the accompanying change from southeastern cyclonic situation into a cyclonic trough and from western anticyclonic into a cyclonic situation (4.2\%). The second most frequent $(19.8 \%)$ sequence after subtype 21 was into cloudy without precipitation (21_10) (Fig. $5)$. This happened most frequently $(18.1 \%)$ in polar maritime old air (PPms) on a day without atmospheric fronts (29.7\%) (Fig. 7). There are no apparent causes of this type sequence between subtypes of weather. The relatively very infrequent change into the subtype 00 (21_00, 2.0\%) was typically accompanied by a change from cy- 


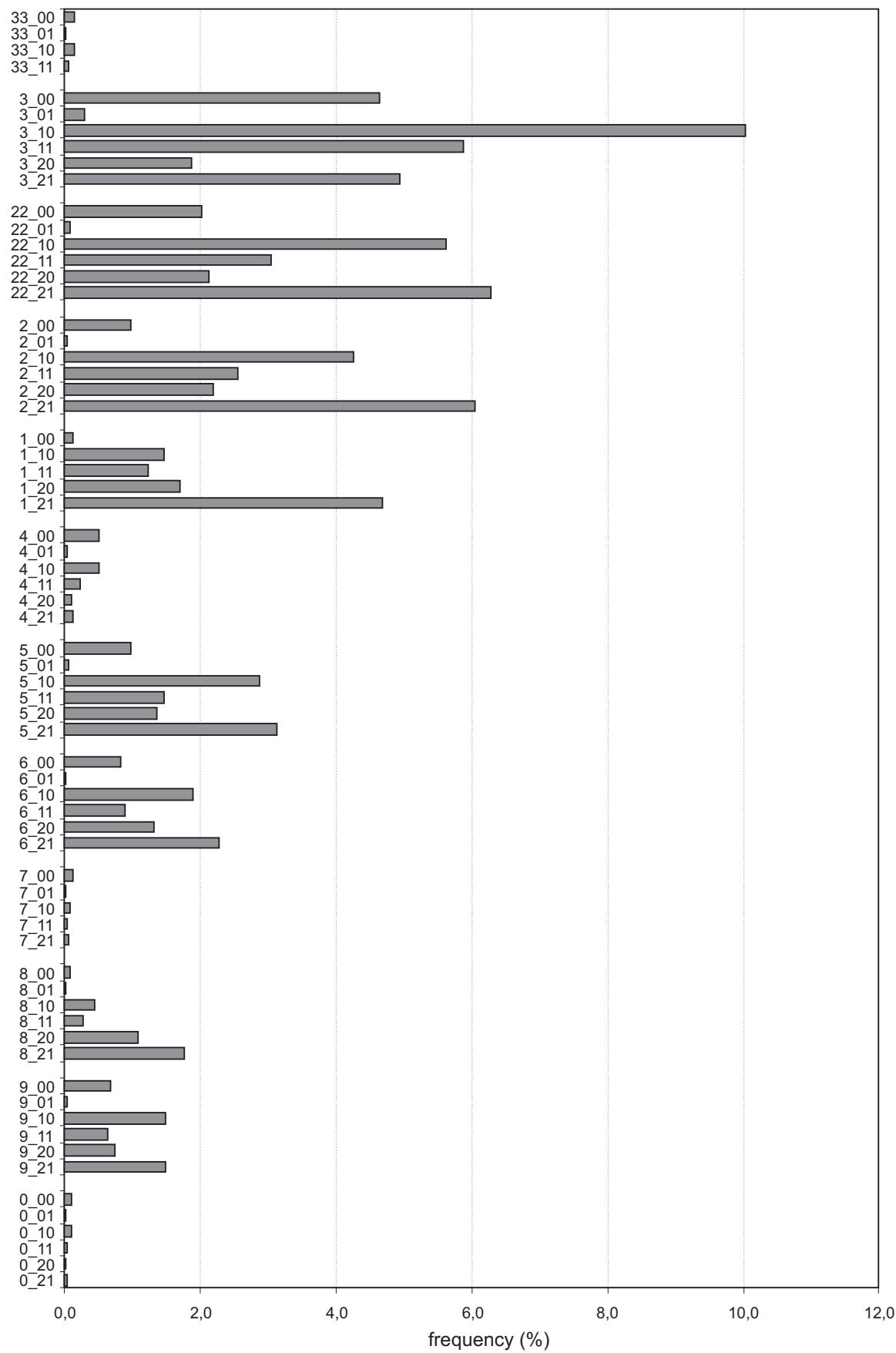

Fig. 6. Frequency of occurrence (\%) of subtype changes of weather in Kraków during the period 1961-2010

clonic to anticyclonic circulation (49.1\%). There does not seem to be a significant influence of this combination from air masses and atmospheric fronts (Fig. 7).

More than $80 \%$ of days with the subtype 11 were followed by either a very cloudy day with precipitation (11_21), a cloudy day without precipitation (11_10), or unchanged weather (11_11) (Fig. 5). The greatest scale of change is represented here by a sunny day without precipitation
(11_00). During the study period, this sequence occurred with the frequency of $4.5 \%$, mostly on days without atmospheric fronts $(37.0 \%)$ in polar marine air masses (PPm, PPms; $19.2 \%$ combined) (Fig. 7). No apparent influences could be identified from circulation types.

A very cloudy day without precipitation (20) was most frequently followed $(83.1 \%)$ by a day with cloudiness above $20 \%$. If for two consecutive days the same circulation type and air mass 
The change of sunny day without precipitation (-00) into cloudy day without precipitation (-10) (00_10)
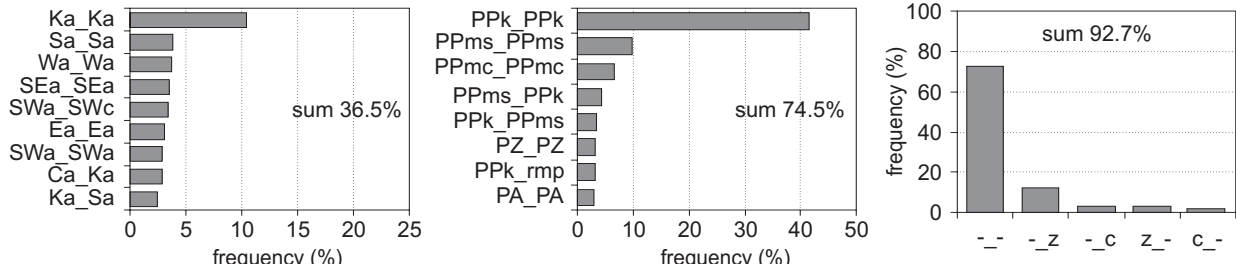

The change of sunny day without precipitation $(-00)$ into very cloudy day with precipitation (-21) (00_21)
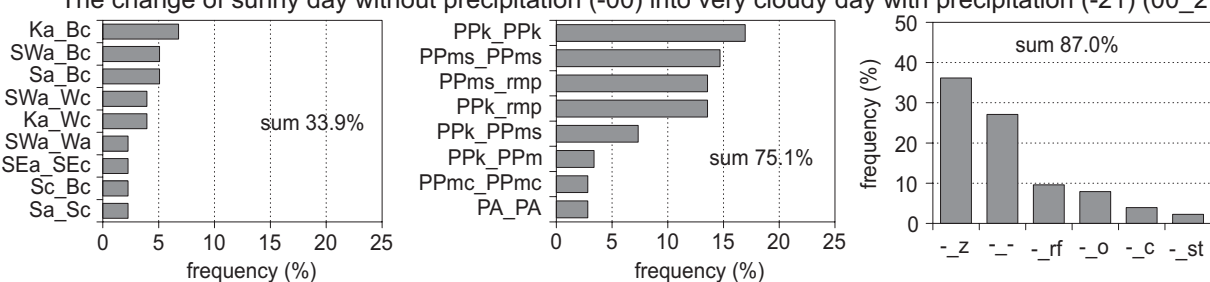

The change of sunny day with precipitation (-01) into very cloudy day with precipitation (-21) (01_21)
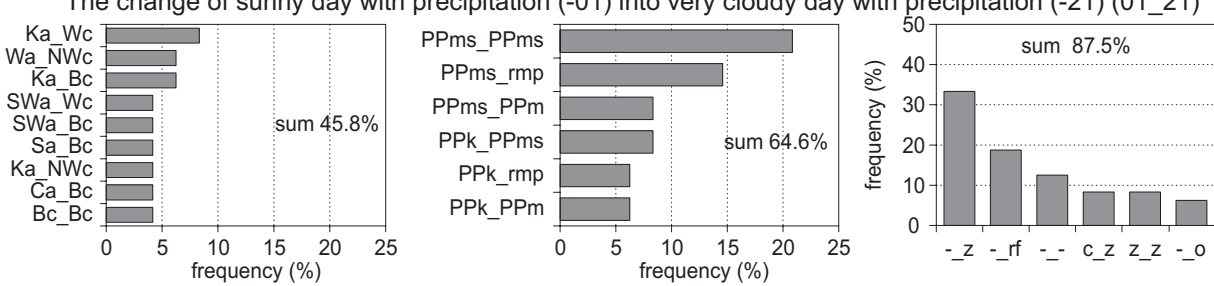

The change of cloudy day without precipitation $(-10)$ into very cloudy day with precipitation (-21) (10 21)
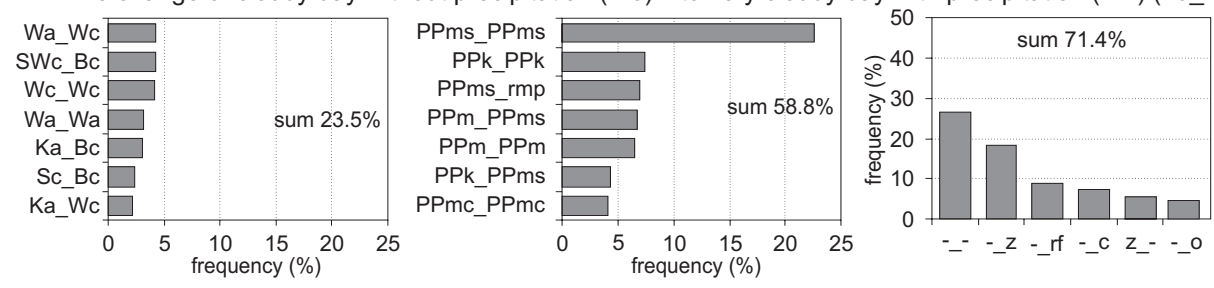

The change of very cloudy day with precipitation (-21) into cloudy day without precipitation (-10) $(21$ 10)
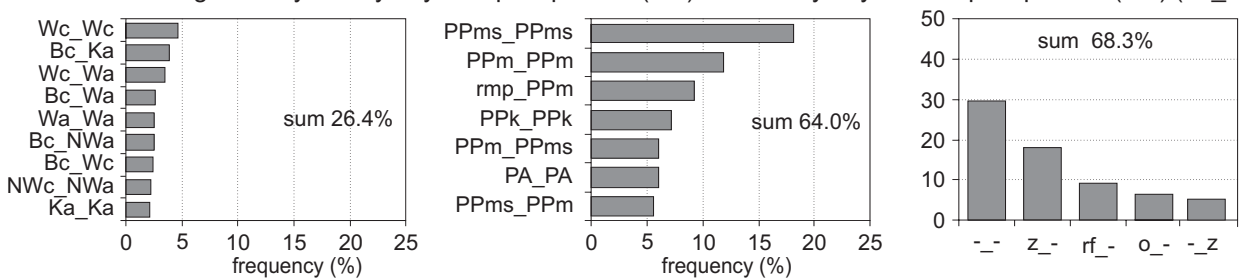

The change of very cloudy day with precipitation (-21) into sunny day without precipitation (-00) $(21$-00)
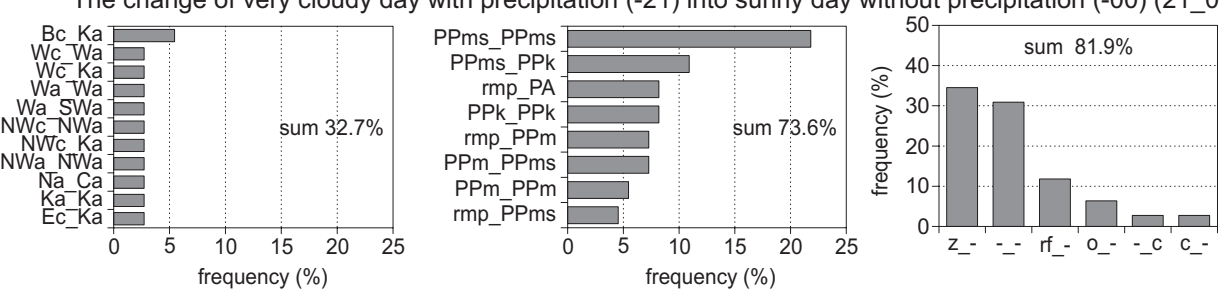

The change of cloudy day with precipitation (-11) into sunny day without precipitation (-00) (11_00)
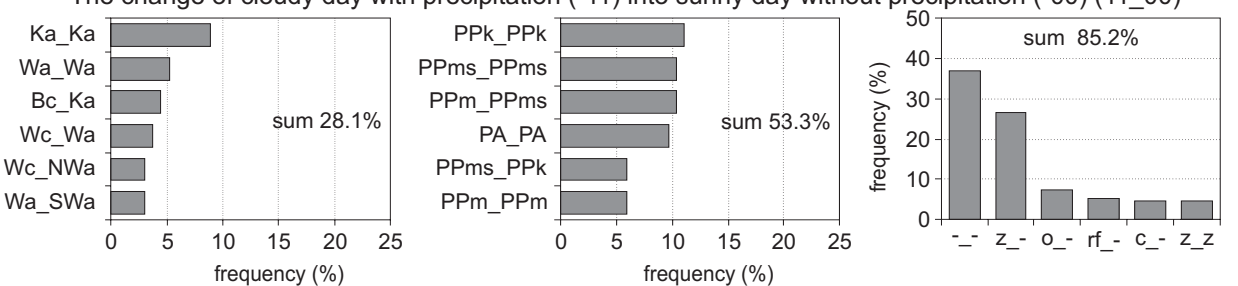

Fig. 7. Frequency of occurrence (\%) of day-to-day change of circulation types, air masses and fronts accompanying changes of selected subtypes of weather in Kraków during the period 1961-2010

See Table 2 for abbreviations 
prevailed and there were no atmospheric fronts over southern Poland then a very cloudy day without precipitation was followed by a dry sunny day (20_00; 5.6\%). The frequency of other dayto-day change combinations is shown in Figure 5.

\section{Day-to-day change of weather types}

The same method was applied to the sequence of weather types as with thermal types and subtypes of weather. The 67 types of weather (Table 1) identified to have occurred in Kraków during the period 1961-2010 had 1059 various potential sequences. Figure 8 depicts the frequency of dayto-day change of some of the most common types of weather. They were divided according to thermal types and for each group the most frequent sequence was also given. The results from this analysis were then compared with the accompanying changes of circulation types, air masses and atmospheric fronts.

During the study period, most of the following days represented the same type of weather as the preceding days (Fig. 8). The four exceptions include three types of weather with ground frost (4-, 5--, 7--) and a frosty type (0--). The most common successor to a day with ground-frost moderately cold weather with clouds but no precipitation (410) was a moderately warm, cloudy day also without precipitation (410_210; 7.1\%) (Fig. 8). This was linked with a stable synoptic situation involving similar circulation and air masses on these days (Fig. 9). A very cloudy day with ground frost, very cold weather and precipitation (521) was typically followed by a cool and very cloudy day with precipitation (521_121; 6.6\%) (Fig. 8). This sequence was normally accompanied by a cold front (-_Z; $13.4 \%)$ and stable western cyclonic circulation (Wc_Wc; $10.9 \%$ ), or its change into the northwestern cyclonic type (Wc_NWc; 10.1\%) (Fig. 9). After a sunny and very cold day with ground frost and no precipitation (700), there followed a moderately cold, cloudy day with ground frost also without precipitation (700_610; 8.2\%). This change was accompanied by two days of anticyclonic circulation type, primarily $\mathrm{Ka}$ and $\mathrm{Wa}$, and polar continental air (Pk). The cause of a change from very frosty and sunny weather without precipitation (000) into very frosty and cloudy without precipitation
(010) tended to be similar. On both days, the circulation would be anticyclonic, typically Ea, Ka or $\mathrm{Ca}$, accompanied by polar continental air (Pk).

Another interesting sequence is a change from 610 to 521. It would be accompanied by a similar circulation type (Wa; $10.3 \%$ ) or by a change from a high to a low-pressure system, e.g. from an anticyclonic wedge into the western cyclonic situation (Ka_Wc; 10.3\%), and by polar maritime old air (PPms; 27.6\%), but no atmospheric front would pass (Fig. 9).

\section{Summary and conclusion}

This paper presents an analysis of the dayto-day change of thermal types, subtypes and types of weather linked with synoptic situations, i.e. circulation types, air masses and atmospheric fronts. During the study period 1961-2010, all combinations of day-to-day weather change were analysed for the frequency of their occurrence using air temperatures, cloudiness and precipitation data from Kraków.

The approach adopted in the study was to begin with an analysis of just the thermal types of weather. There were 69 various combinations of their day-to-day changes and a majority of sequences of the same weather on the following day $(61.3 \%)$. The three dominant sequences included 3_3, 22_22 and 2_2, and were accompanied by an also unchanged synoptic situation. Wherever a change did occur it is worth noting sequences that involved more than one "step" of temperature change. Dramatic weather shifts involving a temperature drop (22_5 and 2_6) were typically linked with a passage of an atmospheric front (mostly cold) and with polar arctic air (PA). Similarly dramatic shifts up the temperature scale (4_22 and 5_22) were associated with polar maritime air.

Weather subtypes were far more susceptible to day-to-day change, and the scale of that change was also quite wide. A dry sunny day $(-00)$ could be followed by a cloudy day with precipitation (-21). This was most frequently linked with a change of an anticyclonic into a cyclonic circulation $(56.5 \%)$ and the passage of a front $(70 \%)$. In only $36.5 \%$ of cases was a cloudy day with precipitation followed by a day without 


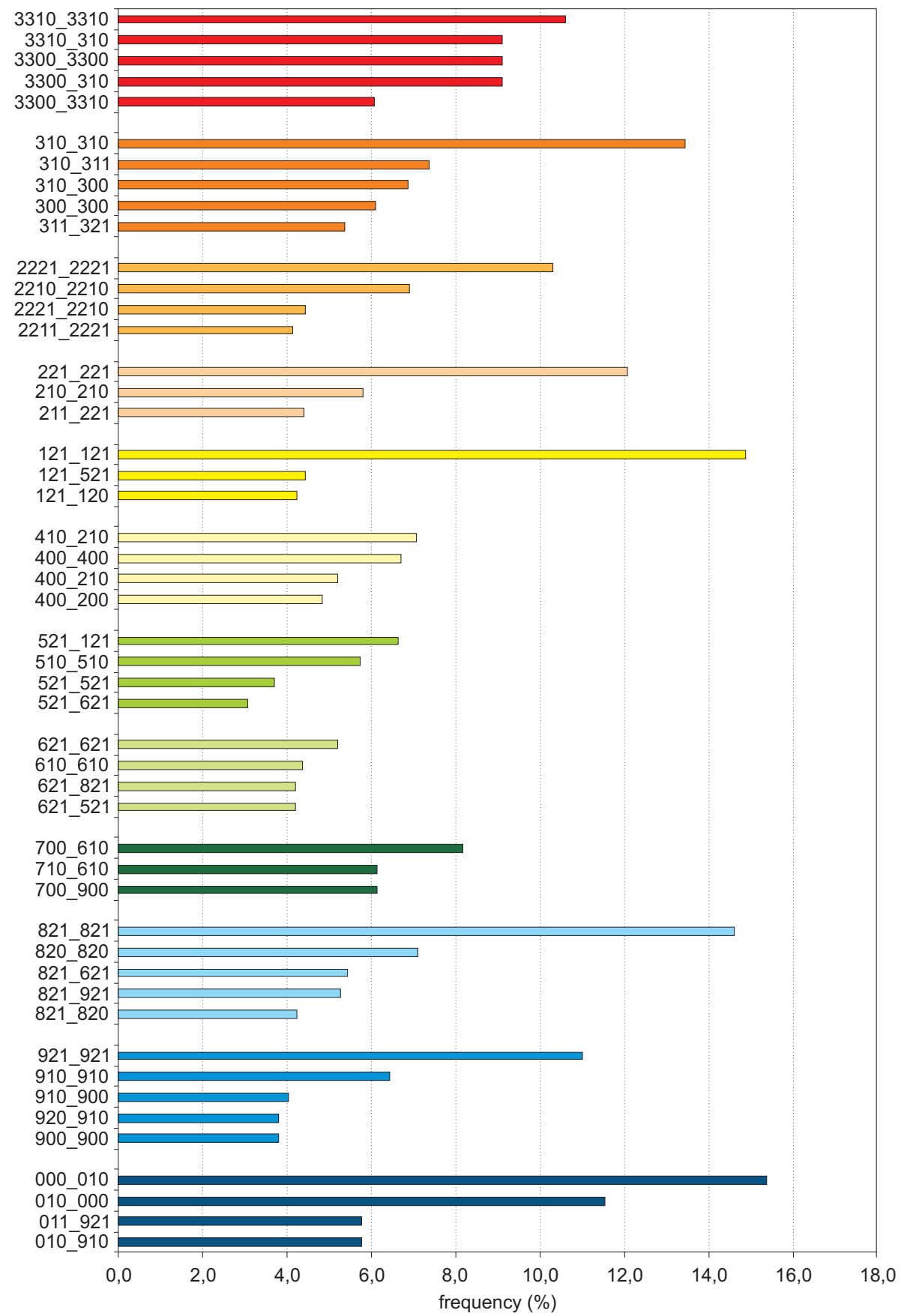

Fig. 8. Frequency of occurrence (\%) of day-to-day change of weather types in Kraków during the period 1961-2010

precipitation. The sequence $-11_{-}-20$ was not explained by any synoptic pattern.

Day-to-day changes of weather types had to do with either a change of air masses or/and passage of atmospheric fronts, while the influence of circulation types was not always clearcut. An example is the change from moderately cool dry cloudy weather with ground frost (410) to moderately warm very cloudy weather with precipitation (221; 410_221). This sort of weather change was mostly accompanied by a stable synoptic situation in terms of circulation types and air masses.

Day-to-day changes of certain types of weather often require an individual approach to their analysis. Each change of types may be caused by a different synoptic situation, and the results of an analysis are not always clear-cut. One suggestion for further research would be to expand the same programme to include seasonality. 


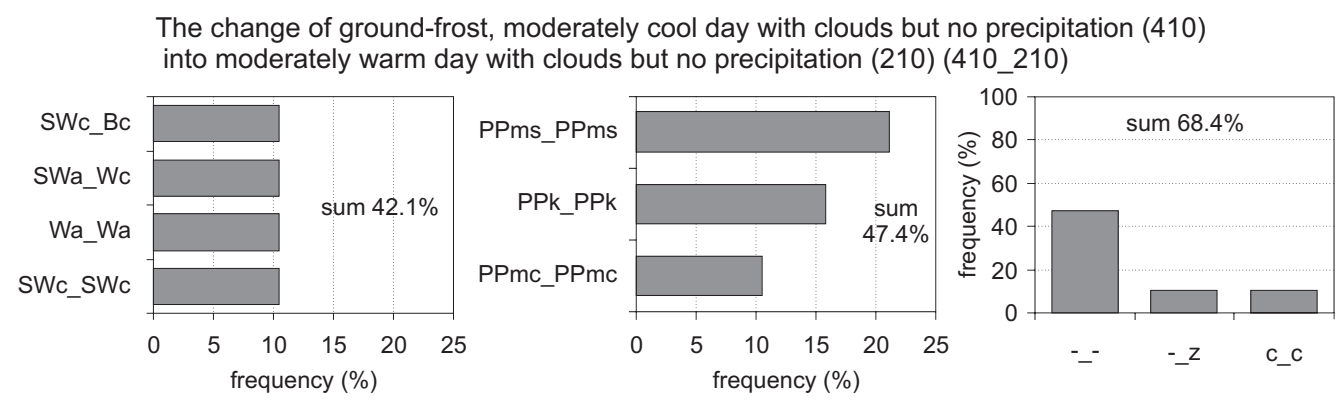

The change of ground-frost, very cool and very cloudy day with precipitation (521)

into cool and very cloudy day with precipitation (121) (521_121)
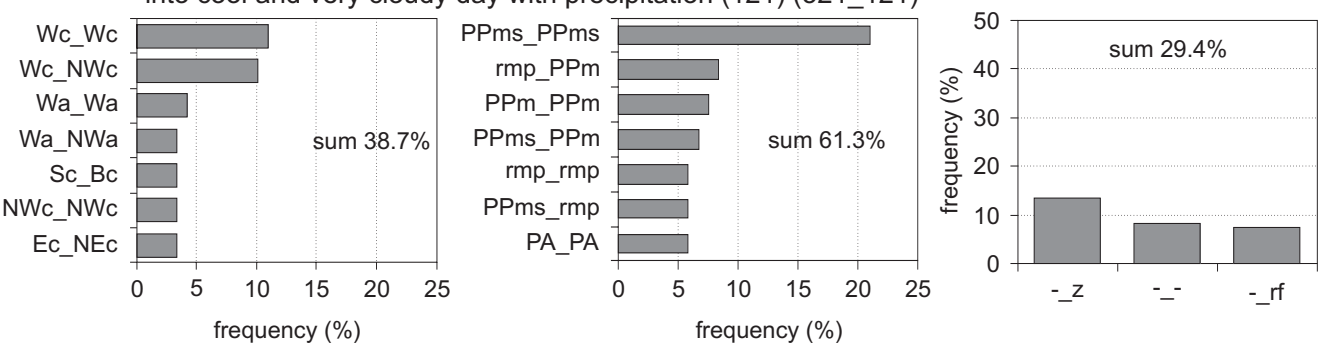

The change of ground-frost, moderately cold and cloudy day with precipitation (610)
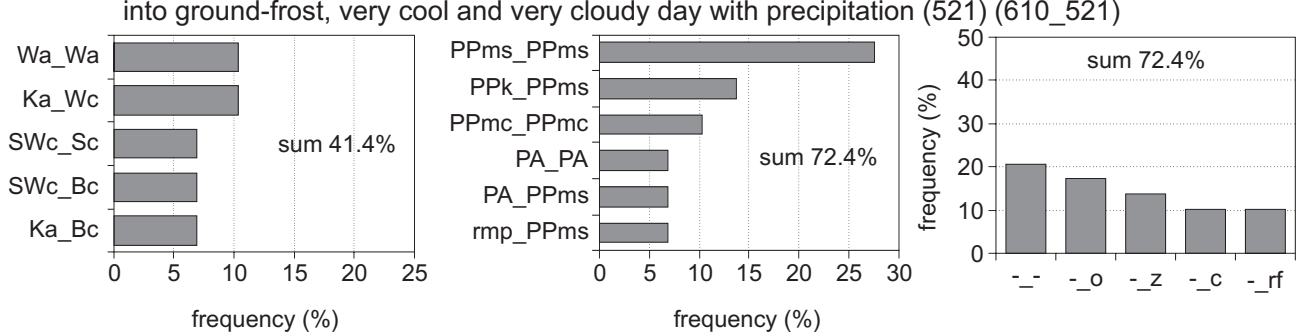

Fig. 9. Frequency of occurrence (\%) of day-to-day change of circulation types, air masses and fronts accompanying changes of selected weather types in Kraków during the period 1961-2010

See Table 2 for abbreviations

\section{Acknowledgements}

The authors are grateful to the Polish-Hungarian bi-lateral project, TÉT_10-1-2011-0037 for the partial support.

\section{References}

Ahas R., Aasa A., Silm S., Roosaare J., 2005. Seasonal indicators and seasons of Estonian landscapes. Landscape Research 30: 173-191.

Bogucki J., Woś A., 1994. Typy pogody a typy cyrkulacji atmosferycznej w rejonie Poznania. Badania Fizjograficzne nad Polska Zachodnią Seria A, 45: 25-42.

Brown P.R., 2004. Weather types associated with extreme temperatures in England. Part 1: Maximum temperatures. Journal of Meteorology 29(294): 358-365.

Chubukov Ł.A., 1949. Kompleksnaja klimatołogia. Izdatielstwo Akademii Nauk SSSR, Moskwa-Leningrad.

Chubukov Ł.A., 1962. Sowriemiennyje osnowy tierieticzeskowo i prikładnowo ispolzowanija kompleksnoj kli- matołogii. Trudy Wsiesojuznowo Naucznowo Mietieorotogiczeskowo Sowieszczanija 4: 59-63.

Fedorov E.E., 1925. Opyt izuczenia pogody miesaca po pogodam otdielnych dniej. Żurnat Gieofiziki i Meteorologii. 2(3-4): 5-16.

Howe G.F., 1925. The summer and winter weather of selected cities in North America. Monthly Weather Rev. 10: 427-429.

Kaszewski B., 1984. Typy cyrkulacji a klasy pogody (na przykładzie danych z Lublina za okres 1951-1975). Sympozjum Naukowe, Skierniewice 1984: 55-56.

Kaszewski B.M., 1992. Typy cyrkulacji a typy pogody w Polsce. Rozprawy Habilitacyjne Wydziału Biologii i Nauk o Ziemi UMCS, 42. Lublin.

Maheras P., 1984. Weather-type classification by factor analysis in the Thessaloniki area. Int. J. Climatol. 4(4): 437-443.

Michailidou C., Maheras P., Arseni-Papadimititriou A., Kolyva-Machera F., Anagnostopoulou C., 2009a. A study of weather types at Athens and Thessaloniki and their relationship to circulation types for the cold-wet period, part I: Two-step cluster analysis. Theor. Appl. Climatol. 97(1-2): 163-177.

Michailidou C., Maheras P., Arseni-Papadimititriou A., Kolyva-Machera F., Anagnostopoulou C., 2009b. A study of weather types at Athens and Thessaloniki and their 
relationship to circulation types for the cold-wet period, part II: Discriminant analysis. Int. J. Climatol. 97(1-2): 179-194.

Nagórska D., 1998. Termiczne typy pogody w Koszalinie a typy cyrkulacji atmosferycznej. Badania Fizjograficzne nad Polska Zachodnia Seria A, 49: 163-169.

Nichols E.S., 1925. A classification of weather types. Monthly Weather Rev. 10: 431-434.

Niedźwiedź T., 1981. Sytuacje synoptyczne $i$ ich wpływ na zróżnicowanie przestrzenne wybranych elementów klimatu w dorzeczu górnej Wisty. Rozprawy Habilitacyjne UJ, 58. Kraków.

Niedźwiedź T., 1983. The method of a synoptic-complex characterization of the climate presented upon the example of the Upper Vistula river basin. Zeszyty Naukowe UJ, Prace Geograficzne 57: 17-39.

Niedźwiedź T., 1988. Wybrane problemy klimatologii synoptycznej. Folia Geographica, Ser. Geographica-Physica 20: 121-134.

Niedźwiedź T., 2013. Kalendarz typów cyrkulacji atmosfery dla Polski południowej. On-line: klimat.wnoz.us.edu.pl/ (accessed 17 January 2013).

Petrovič Š., 1968. Porovnanie typov počasia na Štrbskom Plese podla dynamicko klimatologického a komplexne klimatologického hodnotenia. Meteorologické Zprávy. 21(1): 12-15.

Piotrowicz K., 2010. Sezonowa i wieloletnia zmienność typów pogody w Krakowie. IGiGP UJ, Kraków.

Sheridan S.C., 2002. The redevelopment of a weather-type classification scheme for North America. Int. J. Climatol. 22(1): 51-68.

Sheridan S.C., 2003. North American weather-type frequency and teleconnection indices. Int. J. Climatol. 23(1): 27-45.

Stefanicki G., Talkner P., Weber R.O., 1998. Frequency changes of weather types in the Alpine region since 1945. Theor. Appl. Climatol. 60(1-4): 47-61.

Switzer J., 1925. Weather types in the climate of Mexico, The Canal Zone, and Cuba. Monthly Weather Review 10: 434-437.

Twardosz R., Niedźwiedź T., Łupikasza E., 2011. The influence of atmospheric circulation on the type of precipitation (Kraków, southern Poland). Theor. Appl. Climatol. 104: 233-250.

Więcław M., 2004. Masy powietrza nad Polska $i$ ich wptyw na typy pogody. Wydawnictwo Akademii Bydgoskiej, Bydgoszcz.

Woś A., 1999. Klimat Polski. PWN, Warszawa.

Zinkiewicz W., 1953. Zagadnienie kompleksów pogodowych. Annales UMCS Sectio B, 8(6): 312-341. 